\title{
慢性血液透析患者の脂質代謝異常
}

\author{
遠山純子 \\ 国立王子病院 \\ (昭和 59 年 9 月 21 日受付)
}

\begin{abstract}
key words : hemodialysis, lipid abnormality, post heparin lipolytic activity, apolipoprotein
〈要旨〉

慢性血液透析患者のリポ蛋白代謝の病態を血清脂質濃度, リポ蛋白脂質構成, PHLA, アポ蛋白の所見より検討し, の発生機序について多少の考察を試みた。さらに長期透析の影響および血清脂質に影響するとされる環境因子のい つかについて検討し, 以下の結果を得た。1)慢性腎不全の血清脂質の最も著明な変化は HDL-コレステロールの低 「であり，高トリグリセライド血症は比較的軽度であった。総コレステロールの軽度の低下も認めた。 2)PHLA は著 羽な低下を認めた。男女ともにPHLA とTG は負の相関を示したが, PHAL と HDL-C の相関は男性のみに認めた。 3)LCAT 活性も著明な低下を示し, HDL-C と相関した。 4)1)〜3)より, 透析患者の高 TG 血症はPHLA (LPL) の低 『にもとづくものと思われるが, 低 HDL-C 血症は必ずしも光うではなく, LCAT 活性の低下および关の他複数の因 子に規定されているものと思われる. 5)血清アポ A I, A I , B , E は正常範囲を中心に分布した. アポ C川は血清 TG 濃度と平行して増加していた。したがって LCAT, PHLA (LPL) 両活性の低下はアポ蛋白の量的不足によるものでは ないと思われる，6) 腎不全の血清脂質異常は長期透析により改善する傾向にあった。 7)透析液の組成, 体重は血清脂 質レベルと無関係であった。 ただし急速な体重の増減が脂質に影響する症例もあった。栄養摂取量についても少数例 での検討ではあるが無関係のように思われた。 8)一部の症例では長期透析期間中に誘因の有無にかかわらず脂質レべ ルの大きな変動を示した。
\end{abstract}

\section{Lipid abnormalities in hemodialysis patients}

Junko Toyama, M. D.

Oji National Hospital

Lipid profiles in serum and in each lipoprotein, post heparin lipolytic activity (PHLA), and apolipoproteins were determined in patients undergoing hemodialysis. The effects of hemodialysis and some other factors affecting lipid metabolism were also studied. The results were as follows.

1 ) Hypo-HDL-cholesterolemia was the most frequent abnormality in hemodialysis patients. Hypertrigliceridemia and hypocholesterolemia were also seen. 2 ) PHLA was low in hemodialysis patients and showed a negative correlation with the serum triglyceride level in both men and women, whereas a positive correlation between PHLA and HDL-cholesterol was present only among the men. 3 ) LCAT activity was also decreased and significantly correlated with HDL-cholesterol. 4 ) The hypertriglyceridemia of hemodialysis patients could be due to reduced PHLA, but hypo-HDL-cholesterolemia is not always so. Reduction of LCAT activity and other factors may contribute to the HDL-cholesterol level. 5 ) Serum levels of apolipoprotein A I, AII, B and E. were within normal range. Apo $C$ II concentration was elevated in parallel with the serum triglyceride concentration. Consequently, reductions of LCAT activity and PHLA may not be induced by a decrease of apoproteins. 6) Lipid abnormalities in chronic renal failure tend to be eliminated by long-term hemodialysis. 7 ) Glucose and acetate in dialysate, carbohydrate intake, and body weight were not associated with hypertriglyceridemia. In some cases, rapid weight gain or weight loss affected lipid levels. 8 ) Lipid levels fluctuated markedly in many cases during prolonged dialysis.

遠山 純子 国立王子病院

厂 115 北区赤羽台 4-17-56 (03-907-0551) 


\section{緒言}

慢性血液透析患者のリポ蛋白代謝異常は, 動脈硬化性 病変の促進因子の 1 つとして注目されている。我久は本 稿で，1）慢性血液透析患者の血清脂質の態度，リポ蛋、 白の脂質構成, PHLA およびアポ蛋白の動態等の所見か ら，血液透析の患者のリポ蛋白代謝の病態とその発生機 序について多少の考察を試みた。さらに2）長期血液透 析が血清脂質に及ぼす影響，および血清脂質に影響する といわれている環境因子のいくつかについて検討した。

\section{対象・方法}

測定項目，対象患者数，性別，平均年齢，平均透析期 間を表 1 に示した。対象は国立王子病院および関連病院 で慢性血液透析中の患者群である。なお糖尿病性腎症お よびネフローゼ症候群由来の症例は除外した。

血清脂質 (総脂質：TL, 総コレステロール：TC, 燐脂 質：PL, 遊離脂肪酸：FFA，コレステロールエステル 比：CE/TC) は，昭和 48 年度より月 1 回定期的に測定 してきたが，各パラメーターとの関連については主に昭 和 58 年度 101 例の平均值で検討した。HDL-コレステ ロール $(\mathrm{HDL}-\mathrm{C}), \mathrm{HDL}_{2}$ および $\mathrm{HDL}_{3}$ コレステロール $\left(\mathrm{HDL}_{2}-\mathrm{C}, \mathrm{HDL}_{3}-\mathrm{C}\right)$, および LCAT 活性についても同 じく昭和 58 年度 99 例の平均值について検討した。

\begin{tabular}{l|c|c|c|c|c}
\hline \multirow{2}{*}{ 測 定 項 目 } & \multicolumn{2}{|c|}{ 症 例 数 } & \multirow{2}{*}{ 平均年齢 } & 平均透析期間 \\
\cline { 2 - 5 } & 全 & 男 & 女 & & \\
\hline 血清脂質 & 101 & 63 & 38 & 47.5 & 6 年 1 力月 \\
\hline $\begin{array}{l}\text { HDL コレステロール } \\
\text { 垔分画, LCAT }\end{array}$ & 99 & 62 & 37 & 47.5 & 6 年 1 カ月 \\
\hline PHLA & 35 & 18 & 17 & 51.8 & 6 年 2 力月 \\
\hline 血清アポ蛋白 & 61 & 37 & 24 & 49.0 & 6 年 \\
\hline リポ蛋白脂質分画 & 51 & 26 & 25 & 48.9 & 6 年 1 カ月 \\
\hline
\end{tabular}

表 1 対象と測定項目
PHLA は透析前空腹時にヘパリン $0.1 \mathrm{mg} / \mathrm{kg}$ 静注後 10 分目に測定した . 対象患者数は 35 例で，2 回の測定を 行い，その平均值をとった，血清アポ蛋白值は 61 例の患 者に apo A I , A II, B, CII, Eの 5 種を SRID 法で測 定した.リポ蛋白の脂質分画は 51 例の患者について 2 回 測定しその平均值で検討した。

血清脂質に影響すると考えられる環境因子としては， 透析経過による TC, TG, HDL-C の変動, 透析液の糖 濃度および緩衝液の影響, 患者の食事記録から見た食事 内容との関連, 肥満度との関係について検討し, 最後に 血清脂質の明らかな変動を示した症例を呈示した。

\section{結果}

昭和 58 年度における血液透析患者の血清脂質の平均 值は表 2 , 表 3 に示す通りである. TC の平均値は 172 . $3 \pm 45.6 \mathrm{mg} / \mathrm{d} l$ で正常範囲にあったが，TC $250 \mathrm{mg} / \mathrm{d} l$ 以 上の症例は全 101 例中 8 例 $(7.9 \%$ ） に対し，150 $\mathrm{mg} / \mathrm{d} l$ 以下の症例は 39 例 $(38.6 \%)$ で，低下例が多数を占めた。

TG の平均值は $130.3 \pm 54.4 \mathrm{mg} / \mathrm{d} l$ で同様に正常範囲 にあった. $140 \mathrm{mg} / \mathrm{d} l$ 以上の増加例は 36 例 $(35.6 \%)$ と 全体の約 $1 / 3$ であった。

TL, PL, FFA, CE/TC の平均值もいずれも正常範囲 内にあった。TLが 46 例 $(45.5 \%)$ の症例で低值であっ たが, PL, FFA, CE/TC はほぼ正常範囲内に分布してい る.

HDL-Cの減少は最も著しく, 男 $36.6 \pm 11.4 \mathrm{mg} / \mathrm{d} l$ (正 常 $51.9 \pm 9.8 \mathrm{mg} / \mathrm{d} l)$. 女 $41.1 \pm 11.3 \mathrm{mg} / \mathrm{d} l \quad(60.3 \pm 10.0$ $\mathrm{mg} / \mathrm{d} l)$ といずれも平均值で有意に低下していた。また $\mathrm{HDL}-\mathrm{C} 40 \mathrm{mg} / \mathrm{d} l$ 以下の症例は 99 例中 59 例 (59.6\%) にも達した.すなわちこの症例群での血清脂質の特徽は, 著明な低 HDL 血症と比較的軽度な高 TG 血症および低 TC 血症であった。この傾向は昭和 58 年度に限らず，表 4 に示すように昭和 54〜 57 年度においても TG が 140 $\mathrm{mg} / \mathrm{d} l$ を越える症例が全体の 32〜 39\%であるのに対し $\mathrm{HDL}-\mathrm{C} 40 \mathrm{mg} / \mathrm{d} l$ 以下の症例は 56〜 76\%で低 HDL-C

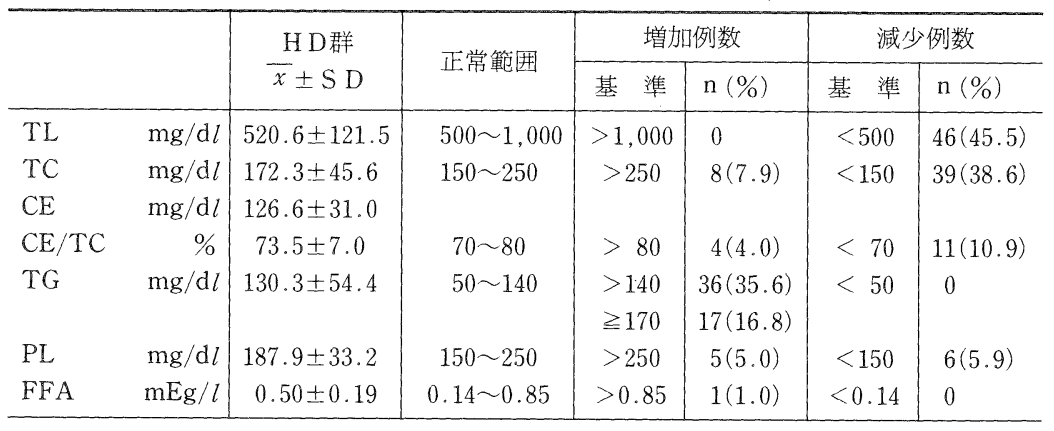

表 2 血液透析患者の血清脂質（58年度平均値， $\mathrm{n}=101$ ) 


\begin{tabular}{|c|c|c|c|c|c|c|c|}
\hline & \multicolumn{2}{|r|}{ H D 群 } & \multicolumn{2}{|r|}{ 正常範囲 } & \multirow{2}{*}{$\begin{array}{c}\text { 隇少率 } \\
(\%)\end{array}$} & \multicolumn{2}{|c|}{ 減 少 例 数 } \\
\hline & $\mathrm{n}$ & $\bar{x} \pm \mathrm{SD}$ & $\mathrm{n}$ & $\bar{x} \pm 2 \mathrm{SD}$ & & 基 準 & $\mathrm{n}(\%)$ \\
\hline $\begin{array}{c}\mathrm{HDL}-\mathrm{C} \\
\text { 男 } \\
\text { 女 }\end{array}$ & $\begin{array}{l}99 \\
62 \\
37\end{array}$ & $\begin{array}{l}38.3 \pm 11.6 \\
36.6 \pm 11.4^{* * *} \\
41.1 \pm 11.3^{* * *}\end{array}$ & $\begin{array}{l}38 \\
36\end{array}$ & $\begin{array}{c}51.9 \pm 9.8 \\
60.3 \pm 10.0\end{array}$ & $\begin{array}{l}-29.5 \\
-31.8\end{array}$ & $\leqq 40 \mathrm{mg} / \mathrm{d} l$ & $59(59.6)$ \\
\hline $\begin{array}{c}\mathrm{HDL}_{2}-\mathrm{C}_{\text {男 }} \mathrm{mg} / \mathrm{d} l \\
\text { 女 }\end{array}$ & $\begin{array}{l}99 \\
62 \\
37\end{array}$ & $\begin{array}{l}25.1 \pm 9.9 \\
22.7 \pm 9.6^{* * *} \\
29.2 \pm 9.3^{* * *}\end{array}$ & $\begin{array}{l}38 \\
36\end{array}$ & $\begin{array}{c}36.7 \pm 8.8 \\
47.7 \pm 11.3\end{array}$ & $\begin{array}{l}-38.1 \\
-38.8\end{array}$ & $\leqq 25 \mathrm{mg} / \mathrm{d} l$ & $59(59.6)$ \\
\hline $\begin{array}{c}\mathrm{HDL}_{3}-\mathrm{C} \\
\text { 男 } \\
\text { 女 }\end{array}$ & $\begin{array}{l}99 \\
62 \\
37\end{array}$ & $\begin{array}{l}16.5 \pm 3.1 \\
16.7 \pm 3.2^{* * *} \\
16.2 \pm 2.8^{* * *}\end{array}$ & $\begin{array}{l}38 \\
36\end{array}$ & $\begin{array}{l}22.2 \pm 3.8 \\
19.2 \pm 3.5\end{array}$ & $\begin{array}{l}-24.2 \\
-15.6\end{array}$ & $\leqq 15 \mathrm{mg} / \mathrm{d} l$ & $40(40.4)$ \\
\hline LCAT & 99 & $47.3 \pm 17.3^{* * *}$ & 74 & $74.4 \pm 21.1$ & -36.4 & $\leqq 50 \mathrm{U}$ & $61(61.6)$ \\
\hline
\end{tabular}

表 3 透析患者の HDL-C と LCAT（58年度平均值）

\begin{tabular}{c|c|c|c|c|c}
\hline & $\mathrm{S} 54$ 年 & $\mathrm{S} 55$ 年 & $\mathrm{S} 56$ 年 & $\mathrm{S} 57$ 年 & $\mathrm{S} 58$ 年 \\
\hline $\mathrm{TG}>140 \mathrm{mg} / \mathrm{d} l(\%)$ & 32.4 & 33.3 & 36.4 & 38.9 & 35.6 \\
$\mathrm{HDL}-\mathrm{C} \leqq 40 \mathrm{mg} / \mathrm{d} l(\%)$ & 76.1 & 62.5 & 58.8 & 56.6 & 59.6 \\
\hline
\end{tabular}

表 4 高 TG 血症, 低 HDL-C 血症の年度別出現率

\begin{tabular}{rl|lll}
\hline HDL-C & $: \mathrm{HDL}_{2}-\mathrm{C}$ & $\mathrm{r}=0.950$ & $(\mathrm{p}<0.001)$ \\
& $: \mathrm{HDL}_{3}-\mathrm{C}$ & $\mathrm{r}=0.428$ & $(\mathrm{p}<0.01)$ \\
$:$ & TC & $\mathrm{r}=0.359$ & $(\mathrm{p}<0.01)$ \\
$:$ & LCAT & $\mathrm{r}=0.393$ & $(\mathrm{p}<0.01)$ \\
TC $:$ LCAT & $\mathrm{r}=0.678$ & $(\mathrm{p}<0.01)$ \\
\hline
\end{tabular}

表 5 HDL-C, TC, LCAT の相関

血症の方が常に高率であった。

HDL-C の覀分画である $\mathrm{HDL}_{2}-\mathrm{C}$ は男 $22.7 \pm 9.6 \mathrm{mg} /$ $\mathrm{d} l$ (正常 $36.7 \pm 8.8 \mathrm{mg} / \mathrm{d} l)$, 女 $29.2 \pm 9.3 \mathrm{mg} / \mathrm{d} l(47.7 \pm$ $11.3 \mathrm{mg} / \mathrm{d} l), \mathrm{HDL}_{3}-\mathrm{C}$ は男 $16.7 \pm 3.2(22.2 \pm 3.8)$, 女

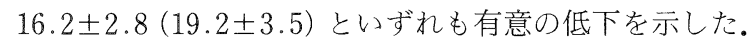

正常範囲の中央値加らの低下率は $\mathrm{HDL}_{2}-\mathrm{C}$ 男 $38.1 \%$, 女 $38.8 \%, \mathrm{HDL}_{3}-\mathrm{C}$ 男 $24.2 \%$, 女 $15.6 \%$ で, $\mathrm{HDL}_{2}-\mathrm{C}$ の低下が著明であった。また $\mathrm{HDL}_{2}-\mathrm{C}$ は $\mathrm{HDL}$ -C と同様女性に高值であったが, $\mathrm{HDL}_{3}-\mathrm{C}$ には性差を

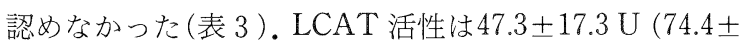
$21.1 \mathrm{U})$, 低下率 $36.4 \%$ で, $\mathrm{HDL}_{2}-\mathrm{C}$ と同様著しく低下し ていた（表 3 ).

$\mathrm{HDL}-\mathrm{C}$ と $\mathrm{HDL}_{2}-\mathrm{C}$ は $\mathrm{r}=0.950$ と非常に高い相関を 示し, $\mathrm{HDL}-\mathrm{C}$ の低下が主に $\mathrm{HDL}_{2}-\mathrm{C}$ の低下を反映して いることを示唆していた，HDL-C はまた LCAT とわ ずかながら有意の相関を示した $(\mathrm{r}=0.393, \mathrm{p}<0.01)$. LCATは TCともよく相関した $(\mathrm{r}=0.678, \mathrm{p}<0.01)$ （表 5 ).

表 6 に PHLA の平均値を示した. 正常者 7 例の

\begin{tabular}{c|c|c}
\hline & $\frac{\text { control }}{x} \pm \mathrm{SD}$ & $\overline{\mathrm{HD}}$ \\
& & \\
\hline PHLA & $\mathrm{SD}$ \\
$\mu \mathrm{molFFA} / \mathrm{m} l / \mathrm{min}$ & $0.275 \pm 0.135$ & $0.084 \pm 0.051$ \\
$($ heparin $0.1 \mathrm{mg} / \mathrm{kg})$ & $\mathrm{n}=7$ & $\mathrm{n}=35$ \\
\hline \multicolumn{2}{c}{} & $\mathrm{p}<0.001$
\end{tabular}

表 6 透析患者の PHLA

PHLA の平均值 $0.275 \pm 0.135 \mu \mathrm{mol} \mathrm{FFA} / \mathrm{m} l / \mathrm{min}$ に対 し，透析患者 35 例では $0.084 \pm 0.051$ で著明に低下して いた.なお男 18 例の平均值 $0.091 \pm 0.062$ に対し女 17 例 では $0.077 \pm 0.034$ で, 有意ではないが男性に高い傾向に あった。PHLA と HDL-C, TG 相互の関係を見ると（表 7 ), 男女で異なった傾向を示した。男性では PHLA は TG と逆相関を $(\mathrm{r}=-0.422, \mathrm{p}<0.1), \mathrm{HDL}-\mathrm{C}(\mathrm{r}=0.490$, $\mathrm{p}<0.05), \mathrm{HDL}_{2}-\mathrm{C}(\mathrm{r}=0.492, \mathrm{p}<0.05), \mathrm{HDL}_{3}-\mathrm{C}(\mathrm{r}=0$. $544, \mathrm{p}<0.01)$ とそれぞれ正相関を示し, TG と HDL-C は逆相関 $(\mathrm{r}=-0.585, \mathrm{p}<0.01)$ を示した。これに対し女 性では PHLA と TG の逆相関 $(\mathrm{r}=-0.534, \mathrm{p}<0.02)$, PHLA と $\mathrm{HDL}_{3}-\mathrm{C}$ の正相関 $(\mathrm{r}=0.331, \mathrm{p}<0.1)$ を認めた のみで, $\mathrm{HDL}_{2}-\mathrm{C}$ とはむしろ逆相間を示し, $\mathrm{TG}$ と $\mathrm{HDL}$ -Cの逆相関も認めなかった。

次に血清アポ蛋白值について述べる。血清アポA I, $\mathrm{A} I I, \mathrm{~B}, \mathrm{CII}, \mathrm{E}$ の平均值と正常範囲は表 8 の通りであ る.アポBの減少傾向とアポ CII 増加傾向を認めるが, いずれも有意ではない.図 1 に血清アポ蛋白值の分布を 示した. 図の黒丸は男性, 白丸は女性, 斜線部分は正常 範囲を示す。アポA I, A II，B，Eはいずれも正常範囲 を中心に分布していたが，アポC II は 61 例中 20 例で高 值であった(表 9). 男女別にみるとアポAI，AII，B， CII，E はいずれも有意の性差を示さなかった。ただ HDL-C は女性に高值であるのに A I，AII はむしろわ 


\begin{tabular}{c|c|c|c|c}
\hline & \multicolumn{1}{|c|}{$\begin{array}{c}\text { male } \\
\mathrm{n}=18\end{array}$} & $\begin{array}{c}\text { female } \\
\mathrm{n}=17\end{array}$ & \multicolumn{1}{c}{$\begin{array}{c}\text { total } \\
\mathrm{n}=35\end{array}$} \\
\hline PHLA : TG & $\mathrm{r}=-0.422(\mathrm{p}<0.1)$ & $\mathrm{r}=-0.534(\mathrm{p}<0.02)$ & $\mathrm{r}=-0.459(\mathrm{p}<0.01)$ \\
$:$ HDL-C & $\mathrm{r}=0.490(\mathrm{p}<0.05)$, & $\mathrm{r}=-0.368(\mathrm{n} \mathrm{s})$ & $\mathrm{r}=0.224(\mathrm{n} \mathrm{s})$ \\
$:$ HDL & $-\mathrm{C}$ & $\mathrm{r}=0.492(\mathrm{p}<0.05)$ & $\mathrm{r}=-0.527(\mathrm{p}<0.02)$ & $\mathrm{r}=0.064(\mathrm{n} \mathrm{s})$ \\
$:$ HDL & $-\mathrm{C}$ & $\mathrm{r}=0.544(\mathrm{p}<0.01)$ & $\mathrm{r}=0.331(\mathrm{p}<0.1)$ & $\mathrm{r}=0.409(\mathrm{p}<0.05)$ \\
TG : HDL-C & $\mathrm{r}=-0.585(\mathrm{p}<0.01)$ & $\mathrm{r}=0.051(\mathrm{n} \mathrm{s})$ & $\mathrm{r}=-0.211(\mathrm{n} \mathrm{s})$ \\
\hline
\end{tabular}

表 7 PHLA, HDL-C, TG の相関

\begin{tabular}{|c|c|c|}
\hline & $\begin{array}{c}\operatorname{HD} \text { 群 }(\mathrm{n}=61) \\
x \pm \mathrm{SD}\end{array}$ & $\frac{\text { 正常範囲 }}{x \pm S D}$ \\
\hline apo A I & $122.4 \pm 19.1$ & $119.6 \pm 23.3$ \\
\hline A II & $24.8 \pm 6.3$ & $25.9 \pm 6.6$ \\
\hline B & $81.3 \pm 30.2$ & $94.5 \pm 53.5$ \\
\hline C II & $4.6 \pm 2.7$ & $3.5 \pm 2.0$ \\
\hline $\mathrm{E}$ & $3.9 \pm 1.9$ & $3.7 \pm 1.5$ \\
\hline
\end{tabular}

\begin{tabular}{c|c|c|c|c|c}
\hline & A I & A II & B & C II & E \\
\hline $\begin{array}{c}\text { 増加例 } \\
(\%)\end{array}$ & $\begin{array}{c}9 \\
(14.8)\end{array}$ & $\begin{array}{c}7 \\
(11.5)\end{array}$ & $\begin{array}{c}4 \\
(6.6)\end{array}$ & $\begin{array}{c}20 \\
(32.8)\end{array}$ & $\begin{array}{c}9 \\
(14.8)\end{array}$ \\
\hline $\begin{array}{c}\text { 滅少例 } \\
(\%)\end{array}$ & $\begin{array}{c}6 \\
(9.8)\end{array}$ & $\begin{array}{c}8 \\
(13.1)\end{array}$ & $\begin{array}{c}5 \\
(8.2)\end{array}$ & $\begin{array}{c}2 \\
(3.3)\end{array}$ & $\begin{array}{c}9 \\
(14.8)\end{array}$ \\
\hline
\end{tabular}

表 9 透析患者のアポ蛋白 (II) 異常値出現率

表 8 透析患者のアポ蛋白（I）

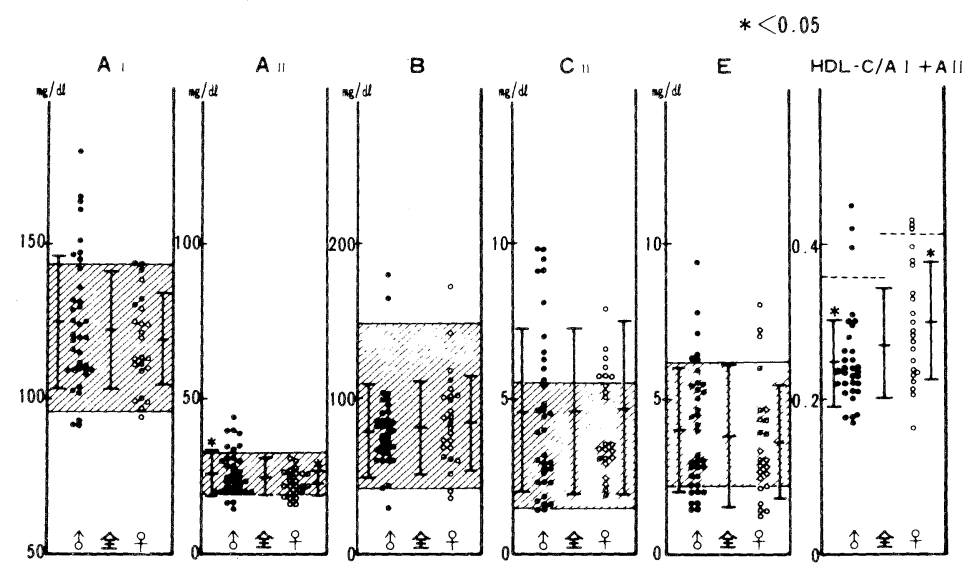

図 1 透析患者のアポ蛋白 $(n=60)$

\begin{tabular}{rl|ll}
\hline apo A I & $:$ HDL-C & $\mathrm{r}=0.490$ & $(\mathrm{p}<0.01)$ \\
& $:$ LCAT & $\mathrm{r}=0.670$ & $(\mathrm{p}<0.01)$ \\
A I AII & $:$ LCAT & $\mathrm{r}=-0.067$ & $(\mathrm{~ns})$ \\
apo B & $:$ TC & $\mathrm{r}=0.790$ & $(\mathrm{p}<0.01)$ \\
& $:$ TG & $\mathrm{r}=0.462$ & $(\mathrm{p}<0.01)$ \\
apo CII & $:$ TG & $\mathrm{r}=0.509$ & $(\mathrm{p}<0.01)$ \\
& $:$ PHLA & $\mathrm{r}=-0.077$ & $(\mathrm{n} \mathrm{s})$ \\
\hline
\end{tabular}

表 10 アポ蛋白と血清脂質の相関

ずかながら男性に高値の傾向にあり, HDL-C/A I + A II比は男 $0.252 \pm 0.065$, 女 $0.0298 \pm 0.078$ とわずかなが ら有意 $(\mathrm{p}<0.05)$ の性差を認めた。また HDL-C/A I + AII の正常値（正常範囲の中央值より計算した值）は男
0.357, 女 0.414 であるので HD 群では男女ともに低下 していた。

表 10 に示すごとくアポA I はHDL-C抢よび LCAT 活性と有意の正相関を示した。A II およびA I + A II も 同じく HDL-C, LCAT と正相関を認めた。しかしA I / A II比は LCAT と全く相関しなかった。アポBは TC および TG と正相関.アポC IIは TG と正相関を示し たが PHLA とは全く相関しなかった。

透析患者のリポ蛋白の脂質分画を表 11 および図 2 に 示した。最も著明な変化は HDL-TCの減少および HDL -PL の減少であった。またVLDL-PL の増加と, 男性 ではLDL-TCの減少も見られた. 全体としては図 3 のご 


\begin{tabular}{|c|c|c|c|c|c|c|c|c|}
\hline & \multicolumn{2}{|c|}{$\mathrm{TC}$ (male) } & \multicolumn{2}{|c|}{$\mathrm{TC}$ (female) } & \multicolumn{2}{|c|}{ TG } & \multicolumn{2}{|c|}{ PL } \\
\hline & $\begin{array}{l}\mathrm{H} \mathrm{D} \text { 群 } \\
(\mathrm{n}=26) \\
\bar{x} \pm \mathrm{SD}\end{array}$ & $\begin{array}{l}\text { 正常範囲 } \\
(\mathrm{n}=58) \\
\bar{x} \pm 2 \mathrm{SD}\end{array}$ & $\begin{array}{l}\mathrm{H} \text { D群 } \\
(\mathrm{n}=25) \\
\bar{x} \pm \mathrm{SD}\end{array}$ & $\begin{array}{l}\text { 正常範囲 } \\
(\mathrm{n}=58) \\
\bar{x} \pm 2 \mathrm{SD}\end{array}$ & $\begin{array}{l}\mathrm{H} \mathrm{D} \text { 群 } \\
(\mathrm{n}=51) \\
\bar{x}+\mathrm{SD}\end{array}$ & $\begin{array}{l}\text { 正常範囲 } \\
(\mathrm{n}=116) \\
\bar{x} \pm 2 \mathrm{SD}\end{array}$ & $\begin{array}{c}\mathrm{HD} \text { 群 } \\
(\mathrm{n}=51) \\
\bar{x} \pm \mathrm{SD}\end{array}$ & $\begin{array}{l}\text { 正常範囲 } \\
(\mathrm{n}=116) \\
\bar{x} \pm 2 \mathrm{SD}\end{array}$ \\
\hline $\begin{array}{l}\text { EDL 分画 } \\
\text { IDL 分画 } \\
\text { ILDL 分画 }\end{array}$ & $\begin{array}{l}35.5 \pm 10.5^{* * *} \\
81.4 \pm 26.4^{* * *} \\
25.3 \pm 13.7\end{array}$ & $\begin{array}{c}53.3 \pm 4.9 \\
110.7 \pm 12.9 \\
28.8 \pm 3.5\end{array}$ & $\begin{array}{l}40.4 \pm 10.0^{* * *} \\
100.2 \pm 27.8 \\
23.8 \pm 12.1\end{array}$ & $\begin{array}{c}59.4 \pm 7.4 \\
109.8 \pm 11.9 \\
26.1 \pm 3.5\end{array}$ & $\begin{array}{l}18.3 \pm 5.1^{* *} \\
39.2 \pm 17.1^{* *} \\
53.6 \pm 27.0^{*}\end{array}$ & $\begin{array}{l}20.5 \pm 3.4 \\
31.4 \pm 4.7 \\
44.8 \pm 11.0\end{array}$ & $\begin{array}{l}73.3 \pm 13.8^{* * *} \\
63.1 \pm 19.6^{*} \\
25.3 \pm 11.3^{* * *}\end{array}$ & $\begin{array}{r}112.7 \pm 7.0 \\
69.0 \pm 6.0 \\
11.8 \pm 4.9 \\
\end{array}$ \\
\hline 計 & $\begin{array}{r}141.9^{* * *} \\
\pm 34.4\end{array}$ & $\begin{array}{l}192.3 \\
\pm 26.9\end{array}$ & $\begin{array}{r}164.3^{* * *} \\
\pm 35.9\end{array}$ & $\begin{array}{r}194.7 \\
\pm 32.0\end{array}$ & $\begin{array}{r}111.2 \\
\pm 40.0\end{array}$ & $\begin{array}{l}112.3 \\
\pm 32.2\end{array}$ & $\begin{array}{r}161.6^{* * *} \\
\pm 29.9\end{array}$ & $\begin{array}{l}192.5 \\
\pm 20.5\end{array}$ \\
\hline
\end{tabular}

表 11 透析患者のリポ蛋白脂質分画

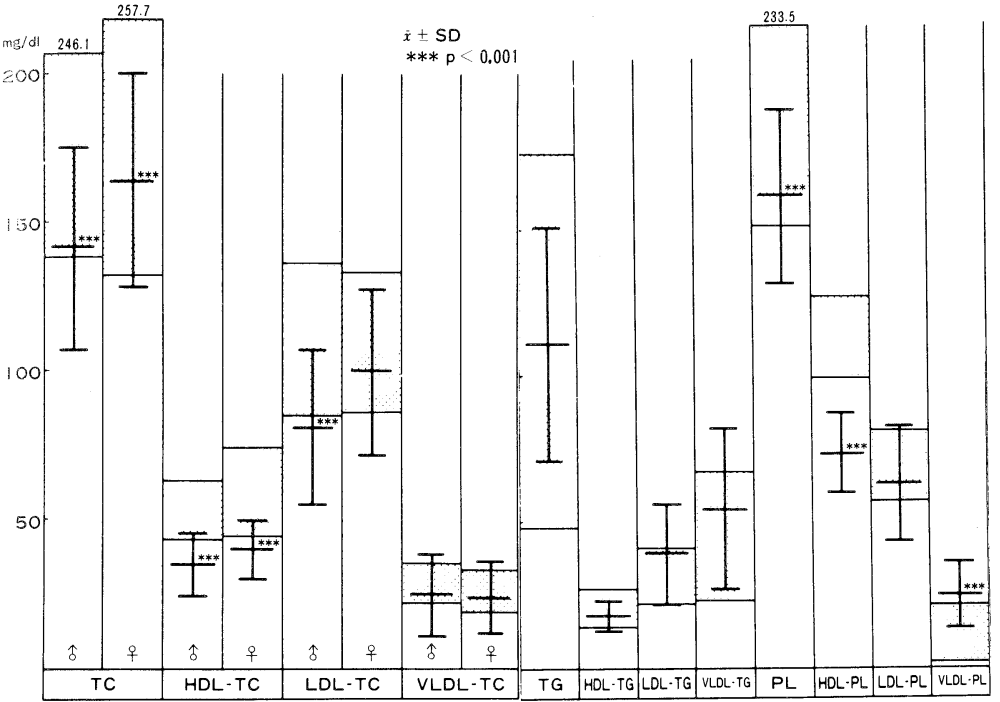

図 2 透析患者のリポ蛋白脂質分画

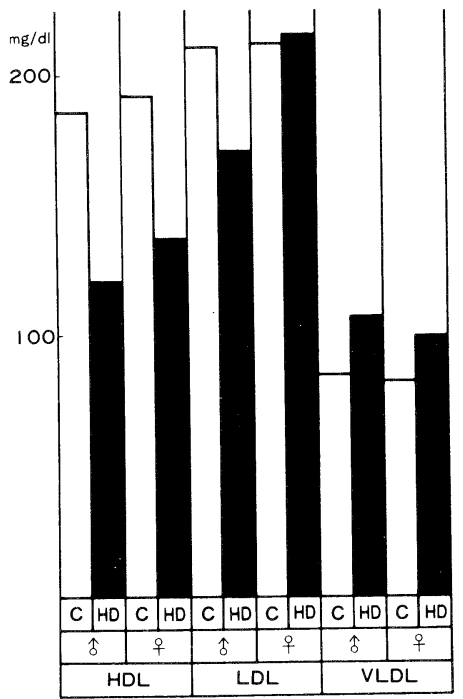

図 3 透析患者のリポ蛋白（脂質部分）
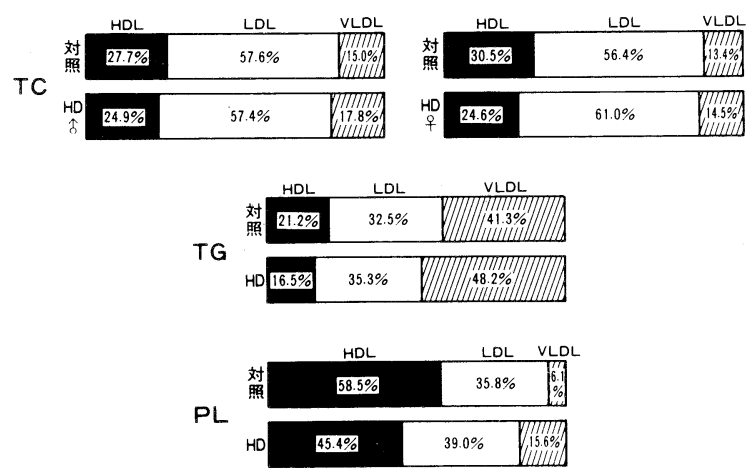

図 4-a リポ蛋白の脂質構成（I）
HDL
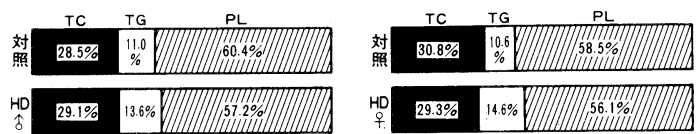

LDL

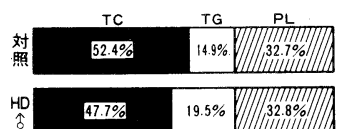

VLDL
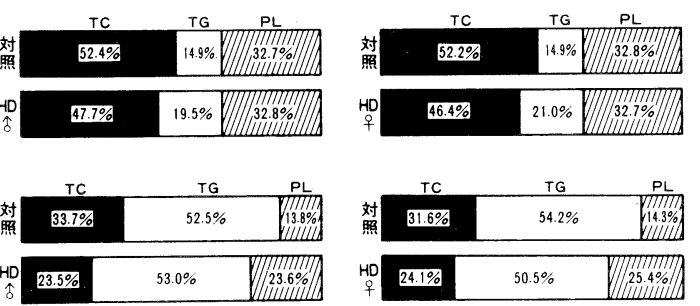

図 4-b リポ蛋白の脂質構成 (II) 


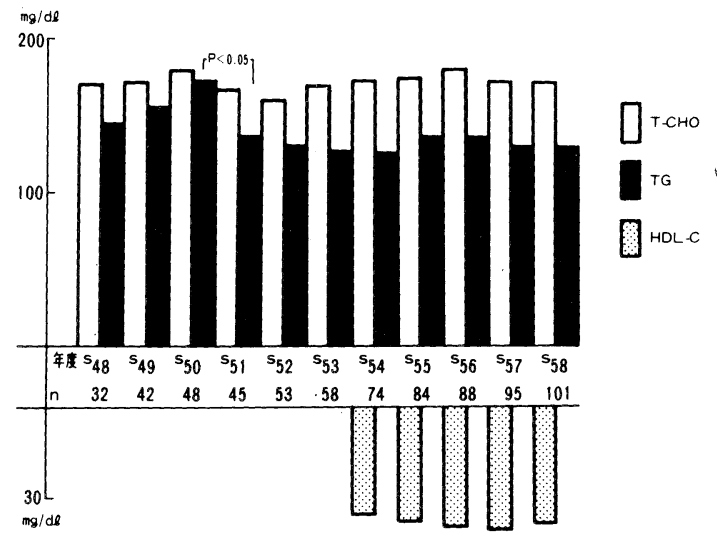

図 5 透析患者の血清脂質の年次変動

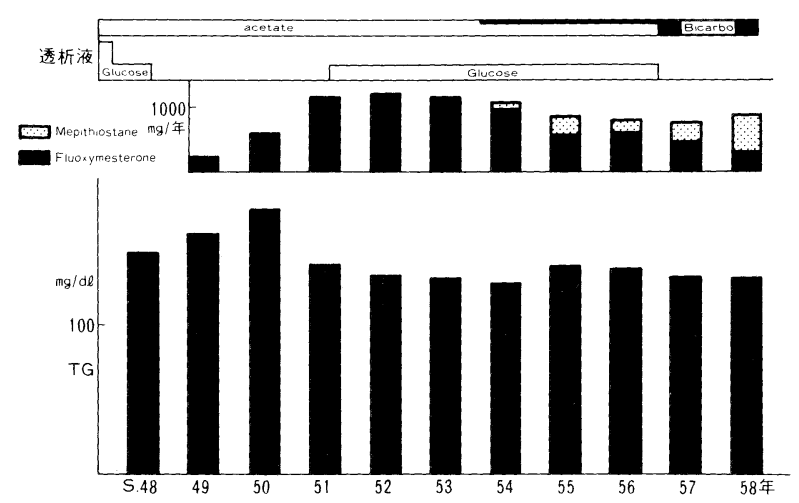

図 6 トリグリセライドに対する透析液㧍よび蛋白同化 ホルモンの影響

\begin{tabular}{|c|c|c|c|c|c|c|}
\hline 年 度 & 対 象 & $\begin{array}{c}\text { エネルギー } \\
(\mathrm{kcal})\end{array}$ & $\begin{array}{l}\text { エネルギー } \\
(\mathrm{kcal} / \mathrm{kg})\end{array}$ & $\begin{array}{c}\text { 蛋白質 } \\
(\mathrm{g})\end{array}$ & $\begin{array}{l}\text { 脂 } \\
(\mathrm{g})^{\text {質 }}\end{array}$ & $\begin{array}{l}\text { 糖 } \\
(\mathrm{g})^{\text {質 }}\end{array}$ \\
\hline \multirow{2}{*}{ S 52 年 } & $\begin{array}{r}\text { 全， 例 } \\
\mathrm{n}=20\end{array}$ & $1,908 \pm 267$ & $39.3 \pm 5.5$ & $55.8 \pm 7.0$ & $64.3 \pm 20.0$ & $269.0 \pm 36.1$ \\
\hline & $\begin{array}{c}\text { 高脂血症 } \\
\mathrm{n}=3\end{array}$ & $1,811 \pm 366$ & $35.2 \pm 7.4$ & $57.2 \pm 5.8$ & $58.9 \pm 16.2$ & $248.2 \pm 40.5$ \\
\hline \multirow{2}{*}{ S58年 } & $\begin{array}{r}\text { 全 } \begin{array}{r}\text { 例 } \\
\mathrm{n}=28\end{array}\end{array}$ & $2,033 \pm 279$ & $42.8 \pm 6.6$ & $67.0 \pm 7.8$ & $69.2 \pm 14.2$ & $270.5 \pm 43.5$ \\
\hline & $\begin{array}{c}\text { 高脂血症 } \\
\mathrm{n}=4\end{array}$ & $2,067 \pm 182$ & $37.4 \pm 2.1$ & $74.0 \pm 12.8$ & $70.4 \pm 5.9$ & $256.2 \pm 25.5$ \\
\hline \multicolumn{2}{|r|}{ 入院一般食 } & 2,000 & & 75 & 50 & 330 \\
\hline
\end{tabular}

表 12 透析患者の食事（S52年と58年の比較）

\begin{tabular}{cc|c|c|c}
\hline $\begin{array}{c}\text { 標準体重よりの } \\
\text { 偏位 }\end{array}$ & $\begin{array}{c}>+10 \% \\
\mathrm{n}=10\end{array}$ & $\begin{array}{c}+10 \% \geqq-10 \% \\
\mathrm{n}=41\end{array}$ & $\begin{array}{c}<-10 \% \\
\mathrm{n}=18\end{array}$ \\
\hline $\mathrm{TC}$ & $\mathrm{mg} / \mathrm{d} l$ & $168.6 \pm 43.5$ & $170.5 \pm 41.4$ & $166.8 \pm 37.7$ \\
$\mathrm{TG}$ & $\mathrm{mg} / \mathrm{d} l$ & $121.4 \pm 45.7$ & $129.1 \pm 51.0$ & $11.2 \pm 23.3$ \\
$\mathrm{HDL}-\mathrm{C}$ & $\mathrm{mg} / \mathrm{d} l$ & $38.3 \pm 8.4$ & $37.2 \pm 10.2^{*}$ & $43.7 \pm 14.2^{*}$ \\
\hline \multicolumn{3}{l}{}
\end{tabular}

表 13 肥満度と血清脂質

とく HDL の著減と VLDL の増加を認め, LDL は男性 で減少していた，次脂質のリポ蛋白への配分の比率を 求めると（図4-a), TC, TG, PLいずれも HDL への分 布が減り, VLDLへの配分が増加する傾向にあった。リ ポ蛋白の脂質構成の面から見ると（図4-b)，HDL では TC, TG, PL とも，ほぼ平行して減少しているため脂質 構成としては TGの微増を除いてはほほ対照群と同様
であった. LDL では TC の比率が減少し, その分 TG が増加していた、VLDLでは TCの比率が減少, PLの 比率の増加が見られた。

以下に血清脂質に影響を及ぼすと考えられる環境因子 に関する成績を述べる。

図 5 に国立王子病院に扔ける TC, TG, HDL-C の年 度別平均值を示した。昭和 50 年度を境に TGレベルは やや低下している，TC，HDL-C はほぼ不変である，脂 質に影響するとされる因子の 1 つに透析液の糖濃度およ び acetate がある. 当院では図 6 上欄のごとく昭和 48 年 3 月まで糖濃度 $554.5 \mathrm{mg} \%$ の acetate 液, 同 3 月より 10 月の間糖 $200 \mathrm{mg} \%$ の acetate 液, 同 10 月より 51 年 9 月の間 glucose free acetate 液, 同 10 月より 57 年 2 月の間再度糖 $200 \mathrm{mg} \%$ 液，この間 54 年 2 月より一部が bicarbonate 液, 57 年 2 月より全部 bicarbonate (glucose free) 液となった。これら透析液の組成と TGレべ 


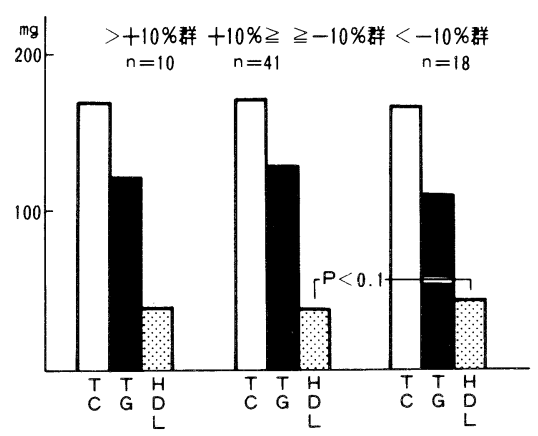

図 7 肥満度と血清脂質

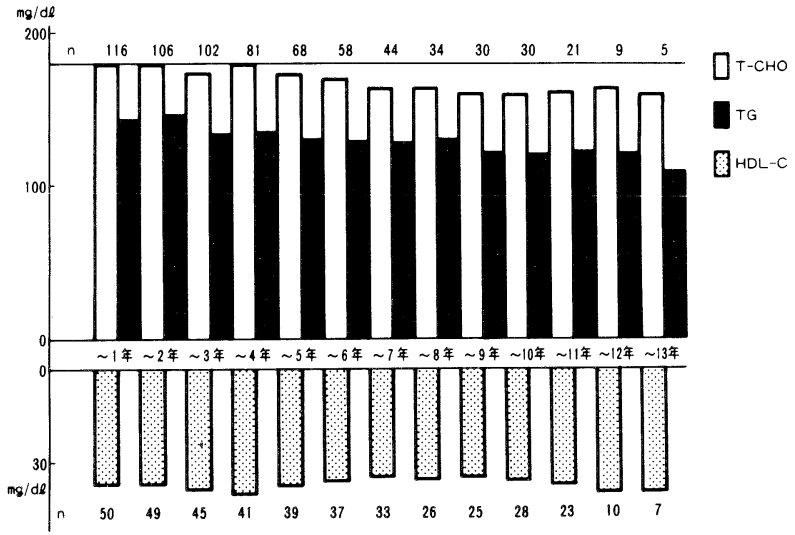

図 8 透析経過による血清脂質の変動

\begin{tabular}{|c|c|c|c|c|c|c|c|}
\hline \multicolumn{4}{|c|}{ 透析導入 3 年目までの変化 } & \multicolumn{4}{|c|}{ 透析導入 5 年目までの変化 } \\
\hline & $\mathrm{TC}$ & TG & HDL-C & & $\mathrm{TC}$ & TG & $\mathrm{HDL}-\mathrm{C}$ \\
\hline 全 症 例 & $\mathrm{n}=76$ & $\mathrm{n}=76$ & $\mathrm{n}=21$ & 全 症 例 & $\mathrm{n}=45$ & $\mathrm{n}=45$ & $\mathrm{n}=6$ \\
\hline 1 年目 & $\begin{array}{l}181.7 \\
\pm 36.4\end{array}$ & $\begin{array}{r}151.5^{* *} \\
\pm 70.4\end{array}$ & $\begin{array}{l}37.9 \\
\pm 8.6\end{array}$ & 1 年目 & $\begin{array}{c}177.2 \\
\pm 32.0\end{array}$ & $\begin{array}{l}149.5 \\
\pm 74.5\end{array}$ & $\begin{array}{l}35.2 \\
\pm 6.7\end{array}$ \\
\hline 3 年目 & $\begin{array}{l}175.0 \\
\pm 40.6\end{array}$ & $\begin{array}{r}129.2^{* *} \\
\pm 55.9\end{array}$ & $\begin{array}{l}42.2 \\
\pm 12.8\end{array}$ & 5 年目 & $\begin{array}{l}175.4 \\
\pm 41.8\end{array}$ & $\begin{array}{c}130.1 \\
\pm 68.2\end{array}$ & $\begin{array}{l}36.8 \\
\pm 11.0\end{array}$ \\
\hline $\begin{array}{l}\text { anabolic } \\
\text { steroids } \\
\text { 非使用群 }\end{array}$ & $\mathrm{n}=49$ & $\mathrm{n}=49$ & & $\begin{array}{l}\text { anabolic } \\
\text { steroids } \\
\text { 非使用群 }\end{array}$ & $\mathrm{n}=24$ & $\mathrm{n}=24$ & \\
\hline 1 年目 & $\begin{array}{l}184.7 \\
\pm 36.6\end{array}$ & $\begin{array}{l}149.4 \\
\pm 58.8\end{array}$ & & 1 年 目 & $\begin{array}{l}179.2 \\
\pm 35.0\end{array}$ & $\begin{array}{l}150.0^{*} \\
\pm 60.9\end{array}$ & \\
\hline 3 年 目 & $\begin{array}{l}184.1 \\
\pm 40.8\end{array}$ & $\begin{array}{l}142.9 \\
\pm 49.0\end{array}$ & & 5 年 目 & $\begin{array}{l}175.7 \\
\pm 45.2\end{array}$ & $\begin{array}{c}127.8^{*} \\
\pm 55.9\end{array}$ & \\
\hline
\end{tabular}

表 14 透析導入後の血清脂質の変動

ルとは無関係のように思われる。図 6 の中闌に患者一人 当りの Fluoxymesterone および Mepithiostane の年間 使用量を示した。これらの薬剤は anabolic steroidsの 中でも抗脂血症作用は弱いものと思われるが，多少の影 響が示唆された。表 12 に当院における昭和 52 年度およ び 58 年度の透析患者の栄養摂取量を示した。これは, 外 来透析患者の食事記録のうち計算可能であった症例， 52 年度 20 例, 58 年度 28 例の栄養摂取量 ( 7 日間の平均) をまとめたものである。両年度とも入院一般食（青年男 子の栄養所要量を基準としたもの）に比し脂質量が多く 糖質の少ない食事内容であった。 58 年度では 52 年度に 比し蛋白摂取量が約 $10 \mathrm{~g}$ 増し，一般食に近づく傾向に あった，蛋白量の増加に伴い脂質も増加していた，血清 $\mathrm{TG} 170 \mathrm{mg} / \mathrm{d} l$ 以上の症例は 52 年度 8 例, 58 年度 4 例で あった。高脂血症の症例が少ないため結論は出せないが, 体重当りのエネルギー量, 糖質摂取量ともむしろ高脂血
症者の方が少な目であった。表 13 および図 7 に肥満度と 血清脂質レベルとの関係を示した. Dry weight が標準体 重の $110 \%$ 以上 $(+10 \sim+37 \%)$ の肥満群，標準体重の $90 \sim 110 \%$ の正常体重群，90\%以下 $(-10 \sim-20 \%)$ の せ群の 3 群間で差を認めなかった。しかし後述のごとく 個々の症例では体重の増減に一致して脂質レベルの変動 を見る症例もあった。次に血清脂質レベルが透析に よって変化するか否かについて検討した。図 8 に全患者 の TC, TG, HDL-C の年度別平均值を透析導入を起点と して集計してみた。透析期間が長期になるにつれて, TC, TG ともに少しずつ低下する傾向が見られた。透析導入 初年度の $\mathrm{TC}$ レベルは $179.1 \pm 38.6 \mathrm{mg} / \mathrm{d} l, 13$ 年目の平 均值は $160.2 \pm 40.6 \mathrm{mg} / \mathrm{d} l$, TG レベルは初年度 $142.8 \pm$ $54.4 \mathrm{mg} / \mathrm{d} l, 13$ 年目 $110.3 \pm 15.0 \mathrm{mg} / \mathrm{d} l$ であった. HDLC は一定の傾向を示さなかった.ただ長期生存例は HDL -Cが高く, TC/HDL-C 比は低かった。次で同一症例に 


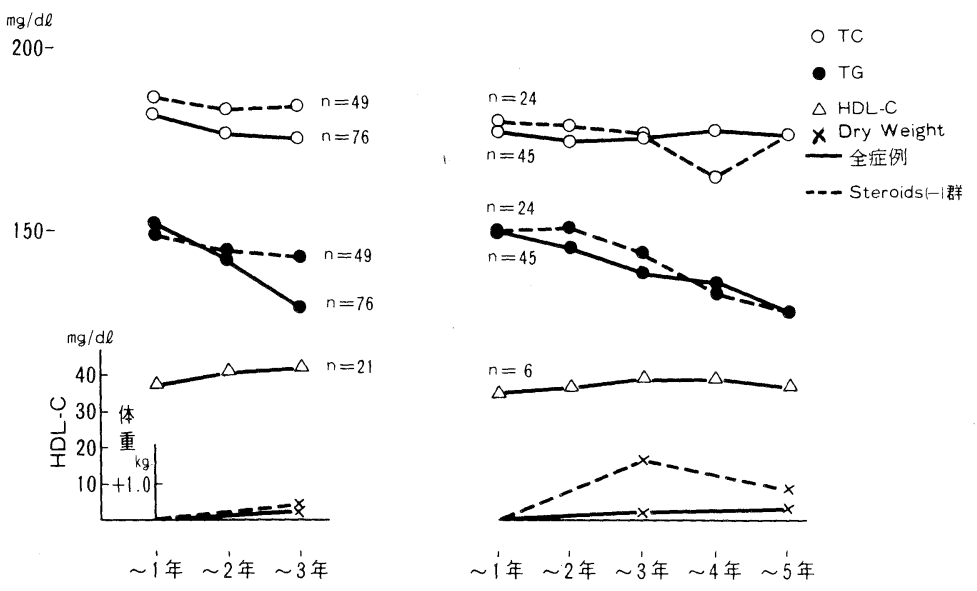

図 9 透析導入後の血清脂質の変動

おける透析の影響を見るために透析導入後 3 年間追跡可 能であった 76 例，および 5 年間追跡できた 45 例につい て各年度の TC, TG, HDL-C の平均值を表 14 および図 9 に示した. 3 年目まで追跡した 76 例では導入初年度の TG は $151.5 \pm 70.4 \mathrm{mg} / \mathrm{d} l, 3$ 年目 $129.2 \pm 55.9$ で有意の $(\mathrm{p}<0.01)$ 低下を示した。しかしそのうち anabolic steroidsを使用しなかった 49 例では有意の低下を示さな かった. 5 年目まで追跡の 45 例の TGは初年度 $149.5 \pm$ $74.5 \mathrm{mg} / \mathrm{d} l, 5$ 年目 $130.1 \pm 68.2$, うち anabolic steroids 非使用の 24 例では初年度 $150.0 \pm 60.9,5$ 年目 $127.8 \pm$ 55.9 でいずれも約 $20 \mathrm{mg} / \mathrm{d} l$ の低下を認めた（anabonic steroids 非使用群のみ有意; $0.05<\mathrm{p}<0.1$ ). TC および HDL-C は導入後 3 年ないし 5 年目までに有意の変化を 示さなかった。

最後に長期透析期間中に血清脂質の著明な変動を示し た症例を呈示する。図10-a 例は導入後約 $13 \mathrm{~kg}$ の体重減少とともに TC, TG が正常化した例, 図10-b

例は導入後急速な体重増加に一致して高 TG 血症 を来した例で体重の増減が脂質に影響したと考えられる 症例である. 図10-c 例は導入後TGレベルの低下 とそれに対応した HDL-Cの増加を認めた例で透析によ る改善例と考えられる。この症例は高 TC 血症を合併し, LCAT 活性は正常範囲にあった。図10-d 例は fluoxymesterone 投与期間中は年々 TGレベルが低下 したが，軽い肝障害のために投薬中止後 TGの再上昇を 見た症例である。図 10-e 例は hemofiltration が 有効であった症例で ${ }^{2)} \mathrm{HF}$ に変更して 2 力月目には TG レベルは正常化した。図 10-f

例は導入以来 8 年 間続いた高 TG 血症が特に誘因と考えられる因子なし に突然低下した症例である。

\section{考察}

慢性腎不全患者の血清脂質の特徵的な変化は, 高 $T G$ 血症と低 HDL 血症であるとされている ${ }^{3)}$. 国立王子病院 における血清脂質の 58 年度の平均値でも, 約 $35 \%$ に軽 度ないし中等度の高 TG 血症を認めたが, 同様の頻度で TCの低下をも認めた。 また血清総脂質も約半数で低下 していた. 当院の透析患者の 58 年度の栄養量は脂肪摂取 量の多いことを除けばほぼ健康人のそれに近く,また体 重の面からも正常体重群が大部分で, 栄養障害による TC 低下は考えにくく, 低 TC 血症も腎不全の脂質代謝 異常の一部と考えるべきであろう. 腎不全の血清脂質異 常で最も目立つ変化は HDL-C の低下で, 低下度, 頻度 ともに, 高 TG 血症より明らかに高度であった。このこ とは高 TG 血症および低 HDL-C 血症の発生機序を考 察する際に考慮すべき要素と思われる。この HDL-Cの 低下は主に $\mathrm{HDL}_{2}-\mathrm{C}$ の低下を反映したもので, 腎不全患 者では $\mathrm{HDL}_{3}$ から $\mathrm{HDL}_{2}$ への成熟障害があるといえる。 この成熟に関与する酵素である LCAT 活性も同様に著 明な低下を示し，HDL-C とわずかながら有意の相関を 示した $(r=0.393, p<0.01)$. 従って LCAT 活性の 低下が $\mathrm{HDL}_{2}-\mathrm{C}$ ひいては HDL-C 低下の原因の 1 つと 考えられる。しかし一方，LCATの著明な低下にもかか わらず CE 比は大部分が正常範囲に属する。これは LCAT が TC と平行して増減しているためで（ $\mathrm{r}=$ $0.678, \mathrm{p}<0.01)$, 肝における両者の合成は相互に関連 して行われているものと考えられる。

近年 HDL の生成機序として, 肝や腸管における合成 の他に, カイロマイクロンやVLDLの LPL による異 化の過程に放出されるルートが重要であるとされ ${ }^{4,5)}$, 正 常者 ${ }^{6,7)}$ および高脂血症者 ${ }^{8)}$ においても LPL 活性と HDL 


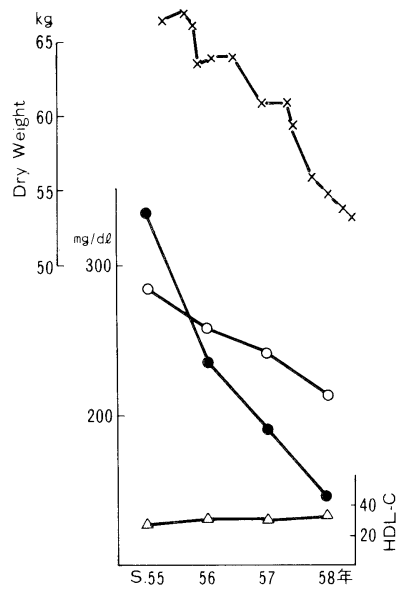

図 10-a

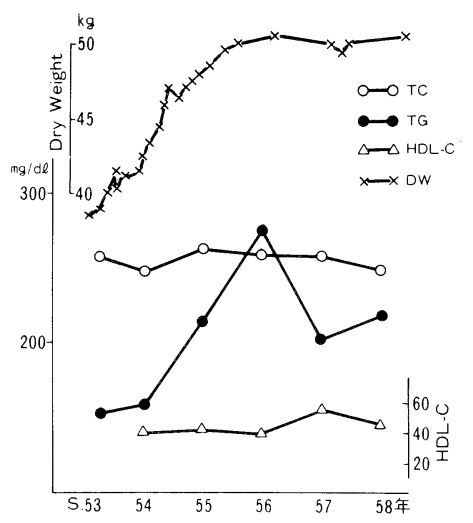

図 10-b

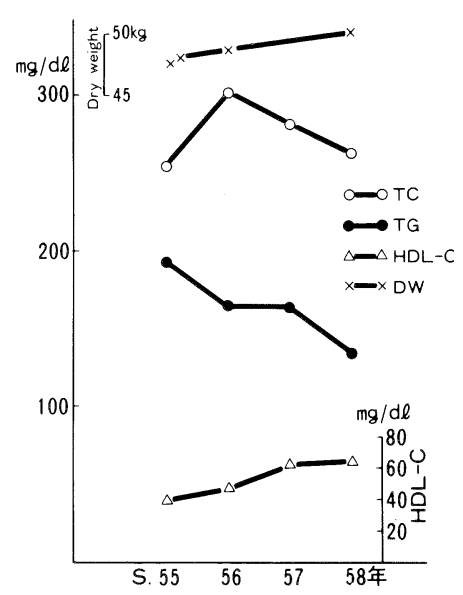

図 10-c
$59 \mathrm{y}$, 우

$58 \mathrm{y}$, 우

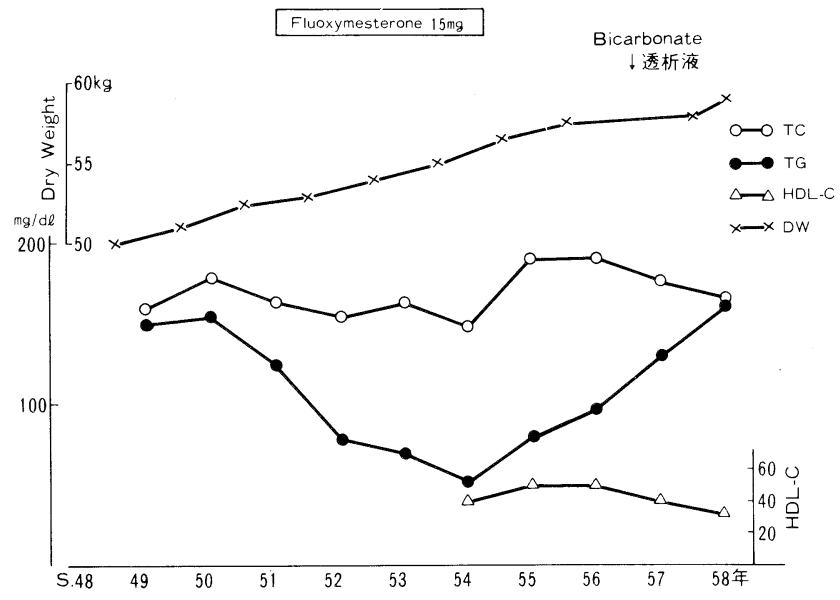

図 10-d

$50 \mathrm{y}, \hat{\delta}$

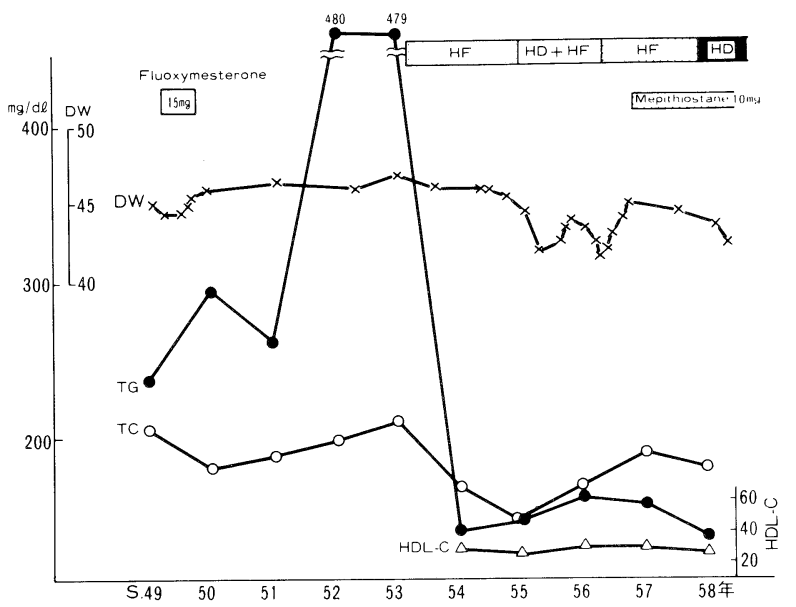

図 $10-\mathrm{e} \quad 59 \mathrm{y}, \hat{\mathrm{o}}$

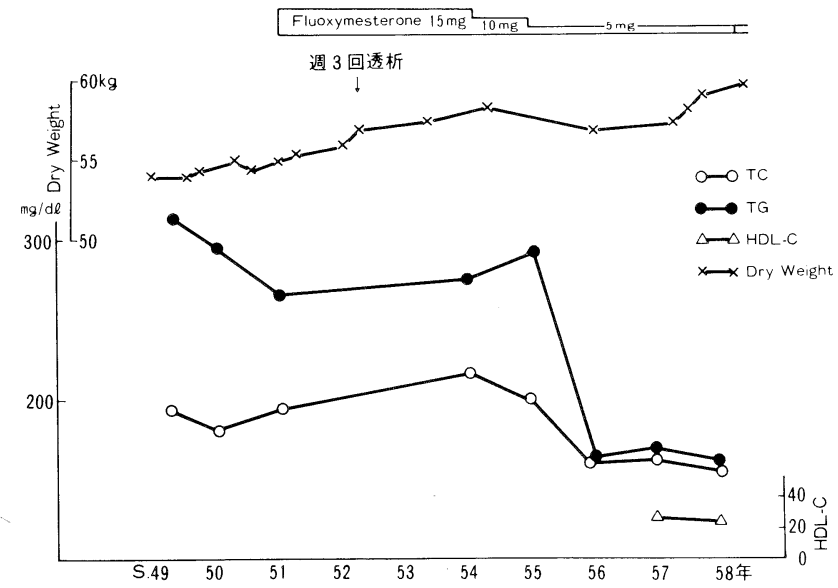

図 $10-f \quad 45 y$, 今

図 10 透析期間中に血清脂質の変動を示した症例 
-C が正相関を示すことから，高 TG 血症と低 HDL 血 症を一元的に説明する報告が多い。透析患者の脂質異常 も同じ機序にもとづくと報告されている ${ }^{9,10)}$

我々の症例においても PHLA は正常対照者の $1 / 3$ 以 下に低下していた。周知のごとく PHLA は肝性 TGり パーゼ (H-TGL) と LPL の合計であり, 正常者の場合 H-TGL が PHLA の 60〜90\%を占めるといわれてい る。腎不全患者の場合 H-TGLが選択的に低下し，LPL は正常であるとの報告がある ${ }^{11,12)}$ 。それが事実であると すれば PHLA は LPL 活性に近いと考元られる。一方， H-TGL，LPL 両活性が低下するとの報告もある ${ }^{9,13)}$. LPL には性差があり，女性に高值で，H-TGL は逆に男

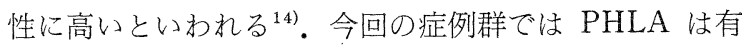
意ではないが男性に高值であった。この点からはPHLA がH-TGLをも含んでおり，両者ともに低下している可 能性もあるが，一応 PHLA が LPL 活性に平行するも のと考えて，TGおよび HDL-C との相関をみた。年の 結果は男，女で大きく態度を異にした。男性ではPHLA と TG, TG と HDL-C の逆相関, PHLA と HDL-C, $\mathrm{HDL}_{2}-\mathrm{C}, \mathrm{HDL}_{3}-\mathrm{C}$ との正相関が得られ，LPL 活性の低 下が高 TG 血症, 低 HDL-C 血症の共通の原因である とする説を裏付けるものであった。しかしこのルートが 低 HDL-C 血症の最も主要な原因であるとすれば, 高 TG 抢よび低 HDL-C はほぼ同様の頻度で出現してもよ いはずである。低 HDL-C の頻度が高 TG 血症の頻度 の 2 倍に近いことを考えると, LCAT 活性低下の影響, 肝や小腸での合成量が減少している可能性なども考慮す る必要があると思われる。一方, 女性では, PHLA と TG の逆相関扔よび PHLA と $\mathrm{HDL}_{3}-\mathrm{C}$ の正相関のみが認め られ, TGレ心゙ルは LPL 活性に関連するが, HDL-C 濃 度は必ずしもそうではないという結果であった。 女性で は estrogenなど,さらに多くの因子が関与しているもの と思われる。な招 PHLA と $\mathrm{HDL}_{3}-\mathrm{C}$ の相関が男女とも に認められたことは興味の兆る点である.VLDLの異化 に際し HDL が分離する過程に 2 つのルトが報告され ている. 1 つはVLDLの core の部分が水解されて収縮 すると, 外表を覆う PL の層が 2 層の sheets として分 離し, 血中の $\mathrm{HDL} と の$ interaction によって円板状の HDL となり，それが LCAT の作用を受けて球状の $\mathrm{HDL}_{2}$ となるというもので,5)，もう1つは LCATを加 えない系に扔いても, LPLによるVLDLの水解に際し, VLDL の成分が $\mathrm{HDL}_{3}$ に転送されて, $\mathrm{HDL}_{2}$-like particle が生ずる ${ }^{15)} と い う も の て ゙ あ る . ~ P H L A ~ と ~ \mathrm{HDL}_{3}-\mathrm{C} の$ 相関は, 生体内での前者のルートの存在を示唆するもの かもしれない.

リポ蛋白代謝に重要な役割を持つアポ蛋白に関する報
告を見ると,アポA-I 関しては腎不全患者では減少す るとの報告 ${ }^{17 \sim 20)}$ と, 減少しないとの報告 $\left.{ }^{22} 24\right)$ とが半ばし ている.この差異の 1 つは, 対象群の HDL-C の減少の 程度によるのではないかと考光られる。 HDL-C はアポ A I と相関しているので, HDL の著明な減少があれば, その構成蛋白である AI も当然減少することが予測さ れる. HDL-C/A I 比については低下するとの報告 ${ }^{20222}$ と不変との報告 ${ }^{19}$ がある。我々の症例では HDL-C/A I 比は低下し, 男性に低い傾向にあった。腎不全の HDLの 減少が脂質に富んだ $\mathrm{HDL}_{2}$ の減少であることを考慮す ると, アポAが正常範囲で脂質部分が減少しているとい う今回の結果牥合理的と思わ机る。な扔アポ A I は LCAT の activator と考えられているが, 実際にアポA I と LCAT は比較的良い相関を示した $(\mathrm{r}=0.670$, $\mathrm{p}<0.01)$. しかし inhibitor と考えられている AII と の比 A I / AII は LCAT と全く相関しなかった. LDL の主要蛋白であるアポBは, LDL の主要脂質である TC とよい相関を示した。主にVLDLの構成蛋白であるアポ Cについては，アポCIIおよびC I が LPLの activator, CIIIが inhibitor と考えられているが，VLDL および HDL のアポCII の減少 ${ }^{25)}$, VLDL の C I + CII/CIII比 の減少 ${ }^{17,18)}$ が報告され, LPL 活性の低下を説明してい る。今回我々はアポ CII の血清值のみを測定したもので あるが, VLDL の主要脂質たる TG と相関して, 増加 例が $1 / 3$ の症例に認められた。またPHLA とは全く相 関しなかった。

以上の結果より, 透析患者のアポ蛋白は総量として減 少していないといえる。したがって, LCAT, LPL (PHLA) 活性の低下は, 酵素量そのものの減少, アポ蛋 白の機能異常, 尿毒症血清の抑制因子の関与 ${ }^{26 ~ 28) な と ゙ に ~}$ 原因を求めるべきかもしれない.

リポ蛋白の脂質構成でも正常対照に比し多少の変化が 見られた。このうち LDLのTGの比率の増加はIDLの 増加 ${ }^{11,29,30)}$ にもとづくものと思われる. VLDL-PL の増 加の理由は不明であるが，PL がリポ蛋白の表面を覆う 極性脂質である点を考元ると, VLDL の小粒子化を示す ものかもしれない。ただVLDL-TC は増加して扔らず, “ $\beta$-VLDL の増加” 関する報告 ${ }^{12,31)}$ とは合致しなかっ た。

腎不全に抢けるリポ蛋白代謝異常にもとづく血清脂質 の異常は, 尿毒症という病態に関連したもので, 血清ク レアチニンの上昇とともに異常が出現するといわれてい る ${ }^{321}$. それが透析によって改善するかどうかという点で は一致を見ていない品 ${ }^{336)}$. 我々のデー夕では透析導入後 血清脂質異常はわずかながら改善するようであった。高 TG 血症を誘発するとされる高エネルギー摂取, 糖質優 
位の食事内容については, 高脂血症症例が少ないため確 定はできないが, 正常脂質群に比し一定の傾向を示さな かった。また透析液の糖濃度, acetate などは TGレべ ルに無関係であった。肥満群, やせ群でも差を見なかっ た。ただ急速な体重の増減が脂質に影響を及ぼした症例 经認められた。

以上より透析患者の脂質に及ぼす環境因子の影響は今 回のデータでは比較的少なく, 脂質異常は腎不全の病態 に関連する部分が大きいと思われた。ただ多数の症例の 長期経過を観察した中で, 血清脂質特に TG 濃度が大き く変動している症例が多いのが印象的であった。すなわ 亏月毎の測定值のばらつきも大きいが, 長期的にも全く 諝因なしに，または体重の増減や薬物投与（anabolic cteroids）に関連して TG レベルの変動を示す症例が見 られた。したがって “normolipidemic”ないし "hyper1pidemic” group は必ずしも固定したものでなく，極端 にいえばその時点での状態を示すにすぎないともいえ る。少なくとも 1 回の測定で両群を分けることは困難と 思われた。

\section{まとめ}

1) 慢性腎不全の血清脂質の特徵的変化は>高 TG 血 症扔よび低 HDL-C 血症とされるが, 血清濃度の平均值, 異常值出現率ともに常に後者において高度であった. TC も高 TG 血症とほほ同様の頻度で低下していた。

2) HD 患者の PHLA は対照群の $1 / 3$ 以下に低下し ていた。男性では PHLA と TG, TG と HDL-C の逆相 関, PHLA と HDL-C の正相関を認めたが, 女性では PHLA と TG は逆相関を示したが, HDL-C とは正相 関を示さなかった。

3 ) LCAT 活性は HDL-C と同様, 著明に低下し, 両者は有意の正相関を示した。

4） 1）～3）より HD 患者の高 TG 血症は PHLA (LPL) の低下にもとづくものと思われるが，HDL-Cの 低下は必ずしもそうではなく，LCAT 活性の低下，抢よ びその他複数の因子により規定されているものと思われ る.

5 ）血清アポA I ，A II， B，Eは正常範囲を中心に 分布した。 C II は血清 TG 濃度に相関して約 $1 / 3$ の症例 で増加していた。したがって LCAT, PHLA (LPL) 両 活性の低下はアポ蛋白の量的不足によるものではないと 思われる。

6 ）腎不全の血清脂質異常は長期透析により改善傾向 にあった。

7 ）透析液の組成，体重は血清脂質レベルと無関係で あった。ただし急速な体重の増減は症例によっては脂質 レベルに影響していた。食事内容についても，少数例で
の検討ではあるが無関係のように思われた。

8 ）長期透析期間中に誘因の有無にかかわらず，脂質 レベルの著しい変動を示す症例が一部に認められた。

\section{文献}

1）久城英人：血漿リポプロテインリパーゼに関する研 究(第一報, 測定法の検討)。臨床病理, $19: 622-626$, 1971.

2) 遠山純子, 小出桂三, 井上昇, 上床 周: $\mathrm{He}$ mofiltration にて著しい改善を示した慢性腎不全高 脂血症の一例。腎と透析, 8:599-603，1980.

3) Chan, M. K., Varghese, Z., Moorhead, J. F. : Lipid abnormalities in uremia, dialysis, and transplantation. Kidney Int., 19 : 625-637 1981.

4) Tall, A. R., Small, D. M. : Body cholesterol removal: Role of plasma high-density lipoproteins. Adv. Lipid Res., 17 : 1-51, 1980.

5) Tall, A. R., Small, D. M. : Plasma higi-density lipoproteins. New Eng. J. Med., 299 : 1232-1236, 1978.

6) Kekki, M. : Lipoprotein lipase action determining plasma high-density lipoprotein cholesterol level in adult normolipidemics. Atherosclerosis, 37 : 143-150, 1980.

7) Nikkilä, E. A., Taskinen, M. R., Kekki, M. : Relation of plasma high-density lipoprotein cholesterol to lipoprotein-lipase activity in adipose tissue and skeletal muscle of man. Atherosclerosis, $29: 497-501,1978$.

8）村瀬敏郎，板倉弘重：血中リポ蛋白リパーゼ活性と HDL-コレステロール濃度。医学のあゆみ，123： 159-160, 1982.

9) Goldberg, A. P., Applebaum-Bowden, D. M., Bierman, E. L., Hazzard, W. R. : Increase in lipoprotein-lipase during chlofibrate treatment of hypertrigriceridemia in patients on hemodialysis. New Eng. J. Med., 301 : 1073-1076, 1979.

10）柏原 昇: 未期腎不全患者の血中脂質に関する臨床 的研究. 透析会誌, $16: 213-223,1983$.

11) Mordasini, R., Frey, F., Flury, W., Klose, G., Greten, H. : Selective defficiency of hepatic triglyceride lipase in uremic patients. New Eng. J. Med., 297 : 1362-1366, 1977.

12）湯川 進, 森下 茂, 宮井利彦, 前田孝夫 : 透析患 者の血清 VLDL-IDL 異常と PHLA (LPL および H-TGL 活性) 変動. 日腎誌，25：717-722，1983. 
13) Applebaum-Bowden, D., Goldberg, A. P., Hazzard, W. R. : Postheparin plasma triglyceride lipase in chronic hemodialysis: Evidence for a role for hepatic lipase in lipoprotein metabolism. Metabo: lism, 28 : 917-924, 1979.

14) Huttunen, J. K., Ehnholm, C., Kekki, M., Nikkilä, A. : Post-heparin plasma lipoprotein lipase and hepatic lipase in normal subjects and in patients with hypertriglyceridemia: Correlation to sex, age and various parameters of triglyceride metabolism. Clin. Sci. Mol. Med., 50 : 249-260, 1976.

15) Patsch, J.R., Gotto, A. M. Jr, Olivecrona, T., Eisenberg, S. : Formation of high-density lipoprotein ${ }_{2}$-like particles during lipolysis of very low density lipoproteins in vitro. Proc. Natl. Acad. Sci., USA, 75 : 4519-4523, 1978.

16) Jansen, H., Tol, A., Hülsman, W. C. : On the metabolic fanction of heparin-releasable liver lipase. Bioch. Bioph. Res. Comm., 92 : 53-59, 1980.

17) Staprans, I., Felts, J. M., Zacherle, B. : Apoprotein composition of plasma lipoproteins in uremic patients on hemodialysis. Clin. Chim. Acta., $93: 135-143,1979$.

18）鵜木哲秀, 平田洋治, 高木大光, 中島洋二, 砂田和 彦, 藤井秀雄, 楠川禮造: 慢性人工透析療法下の尿 毒症患者におけるリポ蛋白異常の成因に関する研究 一 apo 蛋白電気泳動像の検討一. 日腎誌, $24: 37-51$, 1982.

19）湯川 進，永栄政好，宮井利彦，前田孝夫，高橋敏 夫，木下正博，味村啓司，森下 茂，宗 正敏，山 田陽一, 野本 拓, 西出 巌, 西川紀子: 血液透析 患者の血清アポプロテイン A - I および A - II 濃度の 変動。腎と透析, 13:827-832, 1982 .

20）藤井貞人, 山永義之, 古賀俊逸, 井林 博: 血液透 析患者に抢ける血清アポリポ蛋白 A-I A - II濃度お よび HDL-コレステロール濃度の変動. 動脈硬化, 9 : 585-587, 1981.

21) Kobayashi, N., Okubo, M., Marumo, F. : De novo development of hypercholesterolaemia and increased HDL-cholesterol : Apoprotein A-I ratio in patients with chronic renal failure following kidney transplantation. Proc. EDT A, 19 : 505-509, 1982.

22) Rubiés-Part, J., Romero, R., Chacón, P., Masdeu, S., Grinõ, J. Caralps, A. : Apoprotein A and apoprotein $B$ in patients with chronic renal failure undergoing chronic haemodialysis and in renal graft recipients. Nephron, $35: 171-174,1983$.

23) Jung, K., Neuman, R., Precht, K., Nugei, E., Sholz, D. : Lecithin : Cholesterol acyltransferase activity, HDL-cholesterol and apoprotein A in serum of patients undergoing chronic haemodialysis. Enzyme, 25 : 273-275, 1980.

24) Kobayashi, N., Okubo, M., Marumo, F., Nakamura, H. : Effect of dialysis on lipid metabolism in chronic renal failure-Acetate versus bicarbonate. Intern. J. Artif. Org., 6 : 187-190, 1983.

25) Rapoport, J., Aviram, M., Chaimovitz, C., Brook, J. G. : Deffective high-density lipoprotein composition in patients of chronic haemodialysis. New Eng. J. Med., 299 : 1326-1329, 1978.

26) Murase, T., Cattran, D. C., Rubenstein, B., Steiner, G. : Inhibition of lipoprotein lipase by uremic plasma, A possible cause of hypertriglyceridemia. Metabolism, 24 : 1279-1286, 1975.

27) Lutz, W. : The influence of strongly basic peptide on liberation of lipoprotein lipase activity from human adipose cells. Acta Med. Pol., 17 : 55-70, 1976.

28) Lutz, W. : Effect of protein and peptide fractions from the peritoneal dialysate of patients with chronic renal failure on the lipoprotein lipase activity. Acta Med. Pol., 20 : 131-141, 1979.

29) Bolzano, K., Krempeler, F., Sandhoffer, F. : Hepatic and extrahepatic triglyceride lipase activity in uremic patients on chronic haemodialysis. Eur. J. Clin. Invest. $8: 289-293,1978$.

30) Murase, T., Itakura, H. : Accumlation of intermediate density lipoprotein in plasma after intravenous administration of hepatic triglyceride lipase antibody in rats. Atherosclerosis, $39: 293-$ 300, 1981.

31) Norbeck, H. E., Carlson, L. A. : Increased frequency of late pre- $\beta$ lipoproteins $(\mathrm{Lp} \beta)$ in isolated serum very low density lipoproteins in uremia. Eur. J. Clin. Invest., 10 : 423-426, 1980.

32) Frank, W., Rao, T. K. S., Mains, T., Delano, B. G., Avram, M., Saxena, A. K., Carier, A. C., Friedman, E. A. : Uremic hyperlipoproteinemia : Correlation with residual renal function and duration of maintenance hemodialysis. Trans Am. Soc. Artif. Intern. Org., 23 : 59-64, 1977. 
33) Bagdade, J. D. : Uremic lipemia : An unrecognized abnormality in triglycericle production and removal. Arch. Intern. Med., 126:875-881, 1970.

34) Gutman, R. A., Shalhoub, R. J., O'Connell, J. M. B. Recant, L. : Hypertriglyceridemia in chronic non nephrotic renal failure. Amer. J. Clin. Nutr., 26 : 165-172, 1973.

35) Daubresse, J. C., Lerson, G., Plomteux, G., Rorive,
G., Luyckx, A. S., Lefebvre, P. J. : Lipids and lipoproteins in chronic uremia. A study of the influence of regular hemodialysis. Eur. J. Clin. Invest., $6: 159-166,1976$.

36) Huttunen, J. K., Pasternac, A., Vänttinen, T., Ehnholm, C., Nikkilä, E. A. : Lipoprotein metabolism in patients with chronic uremia. Acta. Med. Scand,, 204 : 211-218, 1978.

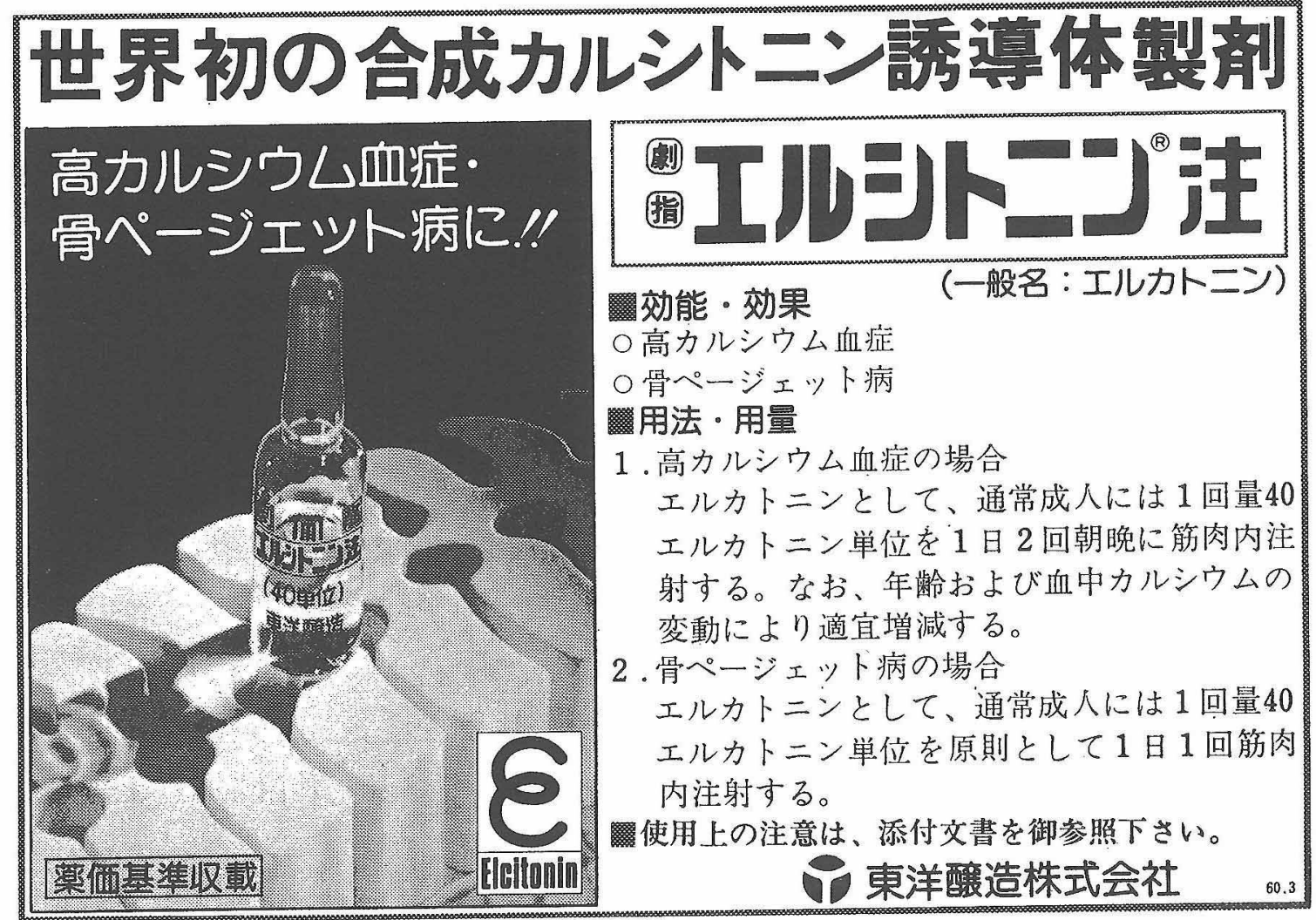

